\title{
La fiesta vigilada de Antonio José Ponte. El archivo bajo sospecha
}

La fiesta vigilada of Antonio José Ponte. The File Under Suspicion

La fiesta vigilada (A festa vigiada) de Antonio José Ponte. $\mathrm{O}$ arquivo sob suspeita

\section{Irina Garbatzky}

UNIVERSIDAD NACIONAL DE ROSARIO/CONICET, ARGENTINA

Investigadora del Consejo Nacional de Investigaciones Científicas

y Técnicas (Conicet) y profesora en la cátedra de Literatura

Iberoamericana I, de la Universidad Nacional de Rosario (UNR).

Doctora en Humanidades y Artes con mención en Letras, por la

UNR. Es autora de Los ochenta recienvivos. Poesía y performance

en el Río de la Plata (Beatriz Viterbo, 2013) y compiló Expansiones.

Literatura en el campo del arte (Yo soy Gilda, 2013). Ha publicado

artículos en distintas revistas académicas como Hispamérica, Katatay,

Orbis Tertius. Correo electrónico: irinagarbatzky@conicet.gov.ar

Artículo de reflexión

Documento accesible en línea desde la siguiente dirección: http://revistas.javeriana.edu.co

doi:10.11144/Javeriana.cl20-40.fvaj 


\section{Resumen}

La autobiografía, el ensayo, la crónica y las imágenes documentales y mediáticas de La Habana vuelven complejo el lugar de la ficción en La fiesta vigilada (2007) de Antonio José Ponte, en el cual la narración se construye como un gran dispositivo de archivación. Sin embargo, más allá del acopio material de documentación histórica y literaria, en La fiesta vigilada Ponte sitúa los discursos que emergen como efecto del mismo acto de documentar: 1) la museificación del pasado y la consagración de la ruina, como producto de la apertura al turismo internacional, y 2) los documentos de la vigilancia y las novelas de espionaje escritas durante la Guerra Fría. En este punto, la recuperación de dicha narrativa le permite al autor reflexionar sobre los alcances de otra política del archivo, donde resulta menos valiosa la conservación intocada del documento o su capacidad de verificar la realidad o la identidad, que su posibilidad performativa de traducir, falsificar, recodificar y, llegado el caso, desmaterializar el dato histórico.

Palabras clave: Antonio José Ponte; narrativa cubana actual; espionaje; comunismo; archivo cubano; literatura cubana

\section{Abstract}

The autobiography, essays, chronic, documentary and media images of Havana, become complex the place of fiction in La fiesta vigilada (2007), of Antonio José Ponte, in which the narrative is constructed as a large device archiving. However, beyond the material collection of historical and literary documents in La fiesta vigilada the speeches placed by Ponte emerging due to a similar act of documenting: (1) museification of the past and the consecration of the wreck, as a result of the opening international tourism, and (2) documents of surveillance and spy novels written during the Cold War. At this point, the recovery of that narrative allows the author to reflect on the achievements of other archive policy, which is less valuable conservation untouched document or ability to verify the identity or reality that its performative ability to translate, falsify, recode and, if necessary, to rationalize the historical data. Keywords: Antonio José Ponte; Cuban narrative; espionage; comunism; Cuban archives; Cuban literature

\section{Resumo}

Autobiografia, ensaio, crônica e imagens documentais e mediáticas de La Habana tornam complexo o lugar da ficção em La fiesta vigilada (2007) de Antonio José Ponte, em que a narração é construída como grande dispositivo de arquivamento. Contudo, mais para além da acervacão material de documentação histórica $\mathrm{e}$ literária, em La fiesta vigilada, Ponte coloca os discursos que emergem como efeito do ato próprio de documentar: 1) a musealização do passado e a consagração da ruína, como produto da abertura ao turismo internacional, e 2) os documentos da vigilância e os romances de espionagem escritas durante a Guerra Fria. Neste ponto, a recuperação de tal narrativa permite o autor refletir sobre os alcances de uma outra política do arquivo, onde resulta menos valiosa a conservação intocada do documento ou a sua capacidade de verificar a realidade ou identidade, quanto a sua possibilidade performativa de traduzir, falsificar, recodificar e, se preciso, desmaterializar o dado histórico.

\section{Palavras-chave: Antonio José Ponte; narrativa cubana atual; espionagem; comunismo; arquivo cubano; literatura cubana}




\author{
"... for what is paranoia if not a practice of forced \\ connections and bad combinations, of my own private archive, of \\ my own notes from the underground, put on display?"

¿QUÉ Significa archivar? En el transcurso de un debate que posee ya numerosos aportes, persiste la pregunta sobre el valor de los archivos. En la crítica literaria y artística aparece relacionada con la idea de una productividad del archivo, que se abriría más allá de las tensiones entre procesos de museificación y de vanguardia, de la espectacularización del pasado o del reciclaje en formato pastiche. ${ }^{1}$ Pero ¿qué queremos decir cuando valoramos que un autor recupere elementos "resistentes", que recupere zonas descartadas de la historia, marginales, olvidadas, utópicas?

En el caso de Cuba, la pregunta cobra nuevos matices. El archivo revolucionario descubre aristas de la temporalidad que se diferencian de aquellas formas de reactivación o desentierro, que fueron sumamente fructíferas para comprender las neovanguardias en el Cono Sur desde la década de los sesenta. Me refiero al aporte insoslayable que resultó el artículo de Hal Foster: "¿Quién le teme a la neovanguardia?", de 1994, no solo para poder pensar las recodificaciones que las neovanguardias realizaron, diferidamente, de los proyectos reprimidos, cortados, de las primeras vanguardias del siglo, sino - sobre todo- para explicar sus efectos en el tiempo, a partir de las categorías freudianas de retorno, represión y acción diferida, que permitieron desmontar la hipótesis del fracaso con la que Peter Bürger había clausurado cualquier posibilidad de recuperación. Para Foster, la acción diferida (Nachträglichkeit) permitía pensar la neovanguardia como reinscripción de un trauma, en un tiempo contado dos veces: "Un acontecimiento únicamente lo registra otro que lo recodifica" (31). Así como la repetición escribe la diferencia, las neovanguardias elaboraron el efecto traumático de su significación en el comienzo de siglo XX; al shock del campo de batalla se sumó la propia

1 Entre la amplia serie de aportes teóricos que vienen discutiendo qué es un archivo, qué significa archivar, qué porvenires tienen los archivos de la modernidad en la actualidad, son ineludibles: Mal de archivo, de Jacques Derrida; La atracción del archivo, de Arlette Farge; En busca del futuro perdido, de Andreas Huyssen; "An Archival Impulse", de Hal Foster, y, por supuesto, la lectura de Michel Foucault sobre el archivo en La arqueología del saber. Trabajé la hipótesis acerca de una puesta en valor de los archivos de la vanguardia a partir de la discusión sobre su productividad en el artículo "El archivo como productor. El lugar del uso en El deseo nace del derrumbe, de Roberto Jacoby". 
sensibilidad que proponían el dadaísmo, el expresionismo o el surrealismo. Se trata de un tiempo reprimido, cuyo resto no cesa de regresar desde un futuro que siempre comprende retrospectivamente la experiencia y, por lo tanto, la recodifica.

En los países del bloque comunista, este esquema para pensar los retornos debe leerse de una manera divergente, ya que presenta singularidades específicas. Susan Buck Morss y Boris Groys lo señalan, al observar la temporalidad singular que supuso la revolución socialista. En Mundo soñado y catástrofe y Obra de arte total Stalin, respectivamente, ambos plantean la suspensión del tiempo de la vanguardia cultural para el caso soviético. No hubo una utopía sin efecto que sepultara los anhelos de revuelta; por el contrario, se trató de una efectuación total y absoluta del programa vanguardista en la instauración de un nuevo presente. A pesar de las persecuciones y de los rechazos de la vanguardia, el estalinismo, según Groys, significó una radicalización y una ejecución a escala máxima de los proyectos artístico-políticos de la vanguardia. Una obra verdadera y consumada de arte colectivo, "aunque el autor de ese programa no haya sido Rodchenko o Maiakovski, sino Stalin, que heredó por el derecho del pleno poder político, el proyecto artístico de aquellos" (Obra 81). La época de Stalin hizo realidad la exigencia fundamental de la vanguardia de que el arte pasara de la representación de la vida a la transformación de esta con los métodos del proyecto estético político total, y así dio por finalizada cualquier idea de utopismo. Habiendo suprimido la oposición entre lo artístico y lo no artístico, lo constructivo y la vida cotidiana, la época de Stalin insistió en "la pretensión de construir un nuevo imperio eterno más allá de los límites de la historia humana", y presentarse a sí misma como "un futuro apocalíptico absoluto en el que la distinción entre futuro y pasado pierde su sentido" (Groys, Obra 144). ${ }^{2}$

2 En Mundo soñado y catástrofe, Susan Buck-Morss realiza una lectura de la cultura soviética tomando como punto de partida el origen común, en los sustratos de la modernidad, del comunismo y del capitalismo, como dos instancias de la cultura de masas y de los sueños colectivos de la modernidad. Esta posición le permite entender de qué modo la revolución bolchevique se había planteado como una instancia superadora de Occidente, "fomentando la tradición revolucionaria mundial hasta su más alta culminación". La idea de la revolución como culminación es tan deudora de Hegel como lo fue la idea de progreso moderna. Sin embargo, coincide con Groys en el punto referido a la constitución política de la temporalidad, por la cual, a pesar de que la vanguardia cultural (avant-garde) y la vanguardia política (vangard), poseían dos temporalidades diversas (la ruptura versus la inserción en una cosmología histórica), la primera cedió a la segunda, con lo cual ser revolucionario implicó afirmar el partido y cubrir sus fracasos. Se trató de una "oportunidad perdida": "la interrupción temporal de la práctica vanguardista podría haber continuado funcionando como una crítica al progreso de la historia después de la Revolución. Se convirtió, por el contrario, en sirviente de una vanguardia política que tenía un monopolio sobre el significado del tiempo, una interpretación cosmológica de la historia que legitimaba el uso de la violencia contra todas aquellas visiones opuestas de la transformación social" (79). 
Más allá de las indiscutibles distancias, históricas, culturales y políticas, entre la Unión Soviética y Cuba, esta diferencia entre la concepción de un presente que busca transformarse hacia un futuro que siempre está por venir y la de un presente que se encuentra con el día después de un futuro ya cumplido se vuelve crucial para pensar la literatura cubana del "Periodo especial". Si ya en Fulguración del espacio. Letras e imaginario institucional de la Revolución Cubana (1960-1971), Juan Carlos Quintero Herencia analizaba de qué modo el sentido de lo revolucionario en los años sesenta cubanos se construía a partir de una "epifanía de visibilidad", que ocupaba por entero el sentido de futuro y entrecomillaba apocalípticamente la realidad o el sentido del presente (18), en los ensayos de los escritores cubanos de fin de siglo XX que pensaron su propia generación vuelve a sonar la reflexión sobre la singular condición y percepción de la temporalidad del comunismo. Iván de la Nuez, por ejemplo, en la antología hecha en 2001, Almanaque: Cuba y el día después, para pensar la literatura cubana contemporánea hace hincapié en el dato del nacimiento de una serie de autores, poco más acá y más allá de 1959. Son "los hijos de la revolución", aquellos niños nacidos y criados durante el comunismo, literalmente soñados como "los hombres nuevos" para Cuba y para el mundo. Son los habitantes de un futuro que cae después de 1989, que da por tierra, a la vez, las ilusiones proyectadas sobre el capitalismo, es decir, haciendo ver que el muro caía hacia los dos lados.

Según De la Nuez, se trata de una generación que creció con la conciencia de encontrarse habitando el futuro del mundo y de que su producción proviene de aquella futuridad:

Si algo saben estos escritores es que no basta con pensar el futuro. Es necesario situarse en él. Y esto a pesar de que se enfrenten, en un acto de esta envergadura, a una paradoja fundamental: el Futuro, así con mayúscula, ya ha

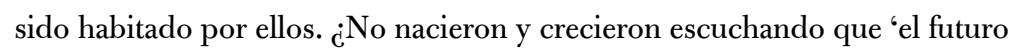
pertenece por entero al socialismo? ${ }_{\mathrm{i}}$ No fueron ellos los elegidos incontaminados, hombres y mujeres que crecerían sin la sombra del capitalismo hasta un mundo sin dinero y sin clases? Ahora, recién despertados del sueño futurista, recién llegados de ese porvenir, se ven conminados a imaginar y vivir un mundo diferente al prometido. Como si se balancearan en una cuerda floja entre el futuro perdido y el futuro posible. (9 y 10$)$

En este punto, volvemos a la pregunta del inicio para indagar cuál será la función de un archivo cuando los restos del pasado parecen no tener ya la productividad redentora que descubría sentidos de un futuro reprimido, aún por desocultar o desarrollarse. ¿Qué significan los archivos 
de un periodo revolucionario, cuando lo que se resguarda, o también se museifica, son los restos de un futuro cumplido? ${ }^{3}$

Se trata de una preocupación que recorre La fiesta vigilada (2007), de Antonio José Ponte: cuáles son los procesos de archivo y museificación en Cuba en los años noventa; qué fantasmas traen a la luz, dónde reside su productividad. Ponte cuestiona y recodifica los procesos de archivación y museificación llevados adelante por el Gobierno durante el "Periodo especial". Pero, aún más, dicho cuestionamiento no deja de verse atravesado, en la escritura del autor, por un propio y singular trabajo de archivo y sistematización de lo cubano, de La Habana y del pasado vinculado con la Guerra Fría. Dicho trabajo, que en algunos momentos el autor llama ruinología, propone otra política de archivo, en la cual se muestra la eficacia que poseen el relato y la ficción para la formulación o invención del pasado histórico. A partir de allí, la escritura de Ponte investiga el encuentro de la melancolía por lo perdido con los vestigios de la paranoia y sus operaciones sobre la realidad. ${ }^{4}$ Estas construcciones se tensan entre la figuración del escritor como "hombre arruinado" y la del escritor recluido y "desactivado", que reflexiona sobre la vigilancia. Si la autorreclusión del escritor cubano posee un antecedente modernista en la figura de Julián del Casal (que vivió en el altillo de la redacción del diario El País, poblado

3 José Quiroga y Duanel Díaz Infante abordan de manera brillante la compleja temporalidad que cobra el tiempo presente en Cuba después de la disolución de la Unión Soviética. Quiroga utiliza la figura del palimpsesto para pensar la memoria cubana durante los años noventa: "In the 1990s, the state continued to write the text of Cuban nationality as it always had, by appealing to a cohesive set of symbols geared toward a future teleology. But at this point something changed. It was the revolutionary past itself-the recent past, not the distant past of the nineteenth century - that gave the nation its sense of identity, and created a sense of cohesive nationalism. At some level, one could say that as a result of the 'Special Period in Times of Peace' the present folded upon itself. [...] Memory in the 1960s was deployed as part of a long narrative leading toward a future, whereas the memorialization of the 1990s celebrated and critiqued the past in order to gain some time in the present" (4). Este presente doblado sobre sí, que absorbe las funciones utópicas y teleológicas del futuro mediante la apelación a la memorialización también es el objeto analizado por Díaz, en la serie de tensiones que despliega en La revolución congelada, a partir de una dialéctica centrada en el corazón de lo moderno: la dialéctica de la ilustración teorizada por Adorno y Horckheimer: "Así como la ilustración, pretendiendo dejar atrás el terreno mítico, se convierte necesariamente en mitología, la aceleración de la historia que pretendió la Revolución [...] ha culminado paradójicamente en su detención, la salida de la isla del tiempo histórico para quedarse en el instante congelado de la Revolución, el instante más largo del mundo" (15).

4 Por supuesto, no me refiero a estas nociones en un sentido clínico, sino apenas como apropiaciones metafóricas para señalar los modos de construcción de ese archivo habanero. 
de elementos de su paraíso decadentista), no parece aleatorio que justo al inicio del libro, para narrar la vuelta de su exilio, Ponte se compare con otra figura decimonónica, también confinada en una torre: Guy de Maupassant, quien, horrorizado por la creación de Eiffel, pasaba horas arriba de la torre, para no ver la torre: "Colocado bajo vigilancia psiquiátrica", dice Ponte, "Maupassant sospechó de un complot médico en su contra. [...] El escritor creía que su voz, apenas susurrada, se escuchaba en la China. [...]. Igual al Maupassant de esa anécdota, mi permanencia en Cuba estaba dictada por el deseo de olvidar. Dentro de Cuba, no veía Cuba" ( $L a$ fiesta 16 y 17).

En los siguientes apartados voy a analizar en qué momentos Ponte encuentra, mediante la recurrencia al archivo del espionaje, una forma de productividad para esa subjetividad bajo sospecha y vigilada, que, en ese no querer ver a Cuba, se la encuentra como un permanente retorno del afuera; en la forma de archivos, registros, libros y museos. Justamente, la Guerra Fría dejó la reactivación de esa impronta paranoica, lo que le permite descubrir el mecanismo de ficcionalización de la construcción archivística, su eficacia: su capacidad de recolectar datos, combinarlos e, incluso, producirlos para que se escriban sobre lo real. Para Freud, la paranoia es un tipo de neuropsicosis de defensa que tiene lugar cuando el yo rechaza una representación intolerable y se conduce como si la representación no hubiese jamás llegado a él, armando un mecanismo de proyección por el cual lo temido adviene como percepción externa. ${ }^{5}$ En La fiesta vigilada, Ponte muestra el camino por el cual la reconstrucción inventada sobre una pérdida no reconocida guía la permanencia de las ruinas habaneras y su museificación. $\mathrm{Al}$ menos tres ideas que aparecen en el libro permitirían seguir este argumento: 1) el motivo ausente para una ciudad en ruinas, sin directa catástrofe bélica o natural; 2) la subjetividad constituida bajo sospecha y a la intemperie, sin resguardo de la mirada o la escucha de los otros, y 3) el modo en que las figuras de la ausencia y la horadación y la carencia recuperan una metáfora recurrente en torno a la condición inmaterial o vacía del archivo identitario cubano.

5 Dice Freud en su artículo de 1924 "La pérdida de realidad en la neurosis y la psicosis" que "En la neurosis se evita, al modo de una huida, un fragmento de la realidad, mientras que en la psicosis se lo reconstruye. [...] O de otro modo todavía: la neurosis no desmiente la realidad, se limita a no querer saber nada de ella, la psicosis la desmiente y procura sustituirla" (195). Para leer específicamente el mecanismo de la paranoia, véase "Observaciones psicoanalíticas sobre un caso de paranoia (dementia paranoides), autobiográficamente descrito (Caso 'Schreber')", de 1910. 


\section{La compulsión archivística}

"Gracias a los informes secretos, la vida de un individuo constituye una vasija rota" (222), dice el narrador de La fiesta vigilada, al recordar una entrevista reveladora, en la ex-Berlín oriental, con G., una persona que había recuperado de la Stasi, en dos grandes carpetas, su expediente; el registro hecho por la policía secreta cuando lo vigiló durante años. Dice también, en el capítulo dedicado a las ruinas habaneras: "Todo espionaje aspira a la simultaneidad de interior y exterior, que es atributo de las ruinas. Lo mismo que el teatro y las operaciones de allanamiento policial, el espionaje recurre a habitaciones de solo tres paredes. Al espía lo empuja la insolencia con que el demonio destapa techos para husmear en los hogares" (203).

En ambas imágenes se presenta un quiebre, una horadación. Según las palabras de Ponte, la caída del muro de Berlín y de la Unión Soviética, en última instancia, habrían reverberado en otra demolición: la del límite que resguarda aquello que a duras penas podría calificarse de "vida interior". Espionaje y ruina, así, se complementan: "Construir ventanas en los corazones y en los secretos pensamientos de los hombres", recuerda el autor que había dicho Francis Bacon, sobre la vigilancia de los credos (202). El techo destapado se proyecta, a su vez, en la dificultad para situar al libro: autobiográfico sin que sea una autobiografía, ensayístico sin que sea un ensayo, narración sin que sea ficción. Como si lo que se edificara en este fuera, al modo en que Gérard Wacjman pensaba al objeto del siglo, una voladura, una ausencia, una implosión.

Sabemos, gracias a Jacques Derrida, que el archivo se orienta hacia ese objeto de reconstrucción imposible. En este sentido, no parece extraño que La fiesta vigilada se presente como un libro de montaje y acumulación. Ponte glosa, transcribe, recupera y comenta, en la gran mayoría de sus apartados, aquello que otros escribieron sobre La Habana, sobre la Revolución, sobre la fiesta, sobre el espionaje. A través de sus anotaciones leemos fragmentos resumidos de Un huracán sobre el azúcar, de Jean Paul Sartre; Viaje a Hanoi, de Susan Sontag; Nuestro hombre en La Habana, de Graham Greene; The File. A Personal History, de Timothy Garton Ash. Volvemos a ver los documentales Buena Vista Social Club, de Wim Wenders; $P M$, de Orlando Jiménez y Sabá Cabrera Infante. Ponte narra a partir de la glosa de estos materiales, rehaciendo su propia lectura frente al lector, y examina, en virtud de dicho procedimiento, los modos por los cuales, tanto para el gobierno revolucionario como para el escritor, hacer ruinas es un arte.

En esta línea, La fiesta vigilada podría segmentarse en dos sentidos. En primer lugar, a partir del archivo de la fiesta y de la Revolución, donde una se ha convertido en la otra: los edificios de la fiesta prerrevolucionaria, ocupados por el 
Estado, luego del "Periodo especial", de cara al turismo internacional, dan lugar a la fiesta que regresa en sus ruinas: bares museificados, música museificada, inteligencia museificada. Un regreso de lo censurado, como menciona Teresa Basile, que es un retorno a lo cubano durante el proceso de desovietización de los años noventa, pero que al mismo tiempo figura el fracaso de los proyectos vinculados a dicha apertura. ${ }^{6}$

Junto a las ruinas, como veíamos al principio, se coloca entonces una segunda cuestión. Se trata de la vida observada, escuchada. La figura del expediente cobra aquí un uso específicamente político. Supone un asunto histórico y un acopio, concreto, burocrático, de las vidas registradas. A lo largo de la escritura de $L a$ fiesta vigilada, y como parte de su propia compulsión archivística - para recordar el modelo que Hal Foster ("The archival impulse") halló en el trabajo de aquellos artistas abocados a recuperar objetos desplazados o desactivados de la historia-, Ponte apela al acervo de las novelas de espionaje, de John Le Carré y de Graham Greene, que entraron en desuso y obsolescencia con el final de la Guerra Fría. Con ello deja al descubierto una política del archivo paralela, muy distinta a la de la museificación de ruinas. El espionaje le permite pensar en la performatividad del archivo, su hacer aparecer y desaparecer mediante las palabras, a través de procesos de falsificación, desmaterialización e invención. Sobre todo porque antes que registrar la realidad o conservar sus restos, el espionaje arma un tipo de ficción particular, que produce efectos discursivos y jurídicos sobre los cuerpos. Como figuración de los procesos de vigilancia y de muerte civil, el espionaje descubre el estallido que provoca la multiplicación de relaciones que recaen en el sujeto observado y escuchado, el desbaratamiento de cualquier estatuto unívoco de verdad; y con ello, las relaciones ambivalentes, de fascinación y de horror, de productividad y de denuncia, que dicho retorno establece con lo literario.

\section{Una ruina viviente}

Uno de los cortes que la crítica literaria viene trazando en torno a la literatura cubana de fines de siglo XX se ubica en la década de los noventa, con el inicio del "Periodo especial" y la caída de la Unión Soviética. Se trata, según Rafael Rojas, en El estante vacío, del exilio intelectual y artístico de un enorme grupo de escritores que comenzó su carrera literaria poco después de los años de

6 Dice Basile: "Los noventa - atravesados por un cambio que no es tal, por una fiesta que regresa pero vigilada, por un muro que se demuele pero renace, por una apertura que vuelve a cerrarse - permiten, quizás por este contraluz, mostrar los rasgos más autoritarios de las políticas culturales del régimen que intentan penetrar todos los resquicios" (211). 
mayor radicalización doctrinaria de la Revolución. Dentro de la isla, estos autores organizaron algunos proyectos artísticos heterogéneos, como Paideia, la propuesta de un espacio independiente de sociabilidad intelectual y de difusión cultural, desarticulado por el régimen; las reuniones en la Azotea (la tertulia de la poeta Reina María Rodríguez), o las revistas de corte vanguardista, como Diáspora(s). ${ }^{7} \mathrm{El}$ exilio de Antonio José Ponte, Emilio García Montiel, José Manuel Prieto, Jesús Díaz, Rolando Sánchez Mejías, Carlos Aguilera, Ernesto Hernández Busto, entre muchos otros, no respondió a una oposición directa y unilateral al régimen, sino "al aislamiento y la rigidez de los controles ideológicos y políticos impuestos a la cultura cubana" (Rojas 118). ${ }^{8}$ Desde el exterior de la isla, un frondoso y extendido abanico de producciones literarias, ensayísticas y periodísticas puso en tensión y reconfiguró sus fronteras. Los "hijos de la revolución", apunta De la Nuez, protagonizaron la ruptura más radical que se haya conocido con la tradición y la línea familiar en la historia cubana. La misma generación que nació y creció durante el comunismo, es, asimismo, la que reactivó el cosmopolitismo, habitando y publicando en ciudades tan dispares como Barcelona, México o Praga. "Si gran parte de la nueva novela ha buscado adentro y antes, los nuevos ensayistas se han caracterizado, desde su primer trazado en los años ochenta cubanos, por buscar afuera y después" (11), comenta De la Nuez.

Estas singularidades que se trazan en la subjetividad de la primera generación crecida durante el comunismo, ${ }^{9}$ se escriben en el cuerpo de quien narra en La fiesta vigilada. Se observan, por ejemplo, en esos momentos en los que de cara al mundo exterior que contrapesa las estancias del narrador en la isla -básicamente aquellas en Portugal y Alemania-, el escritor se ve tratado como una suerte de reservorio utópico ambulante, una ruina viviente. Cuando Ponte narra

7 Sobre el proyecto Paideia, conformado por Rolando Prats, Radamés Molina y Ernesto Hernández Busto, puede leerse el dossier coordinado por Rolando Prats e Idalia Morejón, en Cubista Magazine, verano de 2006 (http://cubistamagazine.com/dossier.html). Sobre el proyecto y revista Diáspora(s), dirigida por Rolando Sánchez Mejías y Carlos Aguilera, puede consultarse la reciente edición facsimilar compilada por Jorge Cabezas Miranda: Revista Diáspora(s). Edición Facsímil (1997-2002).

8 Según Rojas, el factor común que conjuga el exilio de dicha generación no reside en un rechazo unilateral a la Revolución cubana. Más que compartir una posición pública, se trata de "la práctica de un conjunto de políticas personales que convergen en el gesto diaspórico de haber abandonado la isla y permanecer fuera de ella" (119).

9 "La generación de los 80 fue la única plenamente producida por el comunismo. Las anteriores llegaron al orden soviético con una juventud, una adolescencia o, al menos, una infancia, vividas en el antiguo régimen republicano", dice Rojas (117). 
los encuentros que le organizan en Berlín, enfatiza el matiz testimonial con que se lo escucha ("La gente quiere escuchar tu testimonio", le dice el teatrista chileno): La conversación durante la cena, que me fue traducida parcialmente, versó acerca de la desgracia de aquel rincón de Alemania a partir de la reunificación. La vida se había hecho más dura desde entonces, y todos allí parecían añorar los días del régimen comunista. [...] Tal vez fuera tema frecuente entre ellos, aunque supuse que me ofrecían sus razones por ser el único que estaba a tiempo aún. (210)

¿A tiempo de qué? Entre la "fantasía roja" — como llamó De la Nuez (Fantasía) a las mitologías que Occidente encarnó en la Revolución cubana-, que resuena en los comensales alemanes, y aquellos otros amigos que le preguntan a qué volvería a la Isla, cuando a todas luces lo han "desactivado" — "Te dejaron salir para que nunca regresaras. ¿No lo entiendes?" (17)—; el libro elabora un contrapunto. Afuera, Ponte es una "ruina viviente" y adentro es un hombre arruinado - "yo era el primero en reconocer que había vuelto a La Habana con el fin de arruinarme" (162). No resulta casual entonces que el sitio en que el autor termine retratándose sea al pie de un monumento de la República Democrática Alemana, elocuente para la figuración de un sujeto que a lo largo de ese viaje ha sido visto como quien encarna sobre sí los signos en ruina de lo utópico: "Caminamos por la orilla del Spree hasta dar con un monumento. Y a la hora de las fotografías me dispuso delante de un amasijo cuyo único valor consistía en haber sido fabricado con pedazos de Muro: chorrearon concreto y las piedras quedaron apresadas como trozos de almendra en un turrón" (208).

En un libro anterior, Cuentos de todas partes del imperio, el protagonista del relato "Un arte de hacer ruinas" se encontraba con Tuguria, la ciudad construida con los restos materiales de la ciudad revolucionaria. Ahora, en La fiesta vigilada, el autor vuelve a preguntar por el valor de la ruina. ${ }^{10}$ ¿Cuál es su función? ¿La conservación, el resguardo de la historia? Así como el profesor D. de dicho relato, aquí Ponte descubre un valor de uso político de la ruina, que no coincide ni con el valor patrimonial ni con el habitacional. Según advierte Arlette Farge en La atracción del archivo, no existe nada tan fascinante como una reliquia que aparezca como prueba de verdad. Por ello cada pieza exige un trabajo, el ingreso

10 Ponte, "Un arte de hacer ruinas" en Cuentos de todas partes del Imperio. A partir de la lectura dicho cuento, María Guadalupe Silva analiza cómo la ficción colabora con los propósitos del ensayo crítico de la identidad cubana, en relación con un programa de relectura, reescritura y desmontaje (71). En este sentido, es importante observar que La fiesta vigilada vuelve a poner en escena la voluntad de descentralización del aparato nacionalista. 
dentro de un orden, un nombre, una narración. Formas de mediación, para elementos que de otro modo sucumbirían como residuos, objetos incomprensibles.

Sería justamente en torno a esta dimensión discursiva donde Ponte acusaría una falta, porque así como los trozos de muro, abarrotados en el monumento en Berlín, las ruinas de La Habana, milagrosamente estabilizadas, también configuran, dice, un "paréntesis", una desconexión.

Soltadas al abandono urbanístico que los convirtió en parques arqueológicos ("Cuba es un parque temático de la Guerra Fría", afirma), se caracterizan por la carencia de un sentido que vincule sus pedazos; especialmente porque, según lo analiza Ester Whitfield, La Habana no tiene ruinas reales, en el sentido romántico del término. Desde los años noventa, las barriadas del siglo XIX de Centro Habana o del Vedado, en avanzado estado de abandono, los proyectos inconclusos de casas y Escuelas de Arte de los años setenta y sesenta, operan como intereses contrapuestos, entre el efecto del bloqueo económico y la construcción de la ciudad como sitio desmantelado, con el fin de sostener la demanda de un mercado global de las imágenes.

La persistencia de las ruinas en La Habana, de este modo, articula un discurso que ordena la ciudad bajo los efectos de una catástrofe. ${ }^{11}$ Esto nos llevaría a pensar que, aun cuando aquella autofiguración de "ruina viviente" mantenga un tono melancólico - la sombra del objeto que cae sobre el yo, según decía Freud en "Duelo y melancolía", y con la cual el yo se identifica-, se vuelve imperioso señalar su advertencia histórica. La Habana es el "escenario de una guerra ocurrida nunca" (203), se explica en La fiesta vigilada. De la inminencia de la destrucción a la ruina en un solo paso, se lleva a cuestas una catástrofe que no ocurrió; o mejor dicho, y para ser más exactos: que ocurrió nunca. Si en Alemania la causa de las ruinas remitía a un episodio concreto, las ruinas habaneras que Ponte describe

11 Entrevistado por Juan Carlos Rodríguez para la revista La Habana Elegante, Ponte señala el intercambio que estableció con Florian Borchmeyer en su documental de 2006 La Habana: arte nuevo de hacer ruinas y las similitudes con La fiesta vigilada, cómo la escritura del libro coincidió con el tiempo de la filmación del documental. En un momento del filme, Ponte comenta: " ¿Por qué tanta ruina, por qué existe una capital devastada como La Habana sin que haya atravesado ninguna guerra, ni ningún desastre natural que la haya dejado así? A mí lo que me interesa es cómo ha sido todo un ejercicio de destrucción, un edificio se arruina en un sitio, un barrio se puede arruinar, pero cuando una capital entera ya es una construcción de la ruina, ya estamos haciendo ruinas, es un arte de hacer ruinas, se están fabricando ruinas. Yo tengo una teoría, que es que todo el discurso de Fidel Castro, desde el inicio, se basa en la invasión norteamericana. La ciudad de La Habana manteniéndose en ruinas se corresponde exactamente con ese discurso. [...] Como la invasión no tuvo lugar, nosotros somos la ruina falsa de esa invasión, de esa guerra que no fue". 
responden a una destrucción expulsada de la cuenta de la historia - configurada por la amenaza de guerra nuclear, durante la crisis de los misiles en 1962-, la cual, sin acontecer, no obstante ordena la ciudad bajo sus efectos. Una guerra-ocurridanunca convierte a los sujetos "arruinados" en "fantasmas", y sobre todo los ubica en el régimen de la sospecha.

\section{El archivo bajo sospecha}

En este punto sería conveniente situar la recuperación del espionaje como aquel archivo en desuso, de novelas que encontraron su caducidad con el fin de la Guerra Fría. En verdad, en La fiesta vigilada, Ponte critica esta idea de obsolescencia. Citando a John Le Carré, imagina que así como con la electricidad no desaparecieron las novelas de fantasmas, tampoco después del fin de la Guerra Fría desaparece el espionaje. Temores más profundos, vinculados con la alteridad, la frontera, y la vivencia de una intimidad expuesta, persisten aún después de su final. ${ }^{12}$ Las referencias clásicas del espionaje norteamericano-soviético, de hecho, no hacen más que reactivar en La fiesta... la cita implícita de la extensa producción y de la popularidad de la novela policial y de contraespionaje cubana durante la década de los setenta, con autores como Luis Rogelio Nogueras o Leonardo Padura, que apuntaban a caracterizar la subjetividad revolucionaria frente a los vicios de la intelectualidad burguesa decadente (López). La figura del espía permanece vigente, entonces, por cuanto permite revelar los mecanismos de producción de la historia y de la identidad nacional. El espía se borra o cambia su nombre, comparte con el fantasma y con la ficción su capacidad de volverse inmaterial.

¿Qué encuentra Ponte en Nuestro hombre en La Habana, de Graham Greene? En principio, la interpretación, irónica y polémica, del expediente como simulación: su protagonista, Mr. Wormold, recibe un pago del extranjero para informar y coordinar una red de espías, absolutamente inventada por él mismo, que investiga un arma secreta, también fabulada por él, gracias a las aspiradoras que vende. Wormold fabrica los informes de sus espías, produce su documentación. Hasta que descubre que el hombre que le inspiró uno de sus espías-personajes

12 "[Fantasma y espía] Persisten por estar hechos de miedos esenciales. Para seguir vivos, tienen suficiente con alguna frontera. Y nuestra facultad de entender peligrosa toda alteridad, nuestras sospechas cifradas al otro lado de cualquier límite, nos harán suponer nuevos fantasmas y nuevos agentes secretos. Cayó un muro, pero cuántas fronteras no permanecen en pie. La electricidad no hace más que marcar de otra manera el perenne contraste entre claridad y sombra. Por lo que fantasma y espía continúan viniendo, visitándonos, desde los nacionalismos y desde la muerte" (Ponte, La fiesta 40). 
es asesinado en la realidad. "No habló de Raúl como si fuera una persona viva", se dice en Nuestro hombre en La Habana, "Se pasó el rato hablando bien de él, como un mal novelista que prepara un efecto" (Greene 131).

Las simulaciones fabuladas cobran espesor en la realidad, solo que aquello que en Greene tenía un final feliz, se encuentra con un callejón sin salida en el contexto cubano. Entre espía, archivista y novelista existe un solo paso, ${ }^{13}$ no obstante lo que se vuelve determinante para una crítica sobre el archivo cubano es que el resultado de lo que tanto unos y otros fabrican es la condición de figuras espectrales, intangibles: figuras de aire. La referencia a $\mathcal{N u e s t r o ~ h o m b r e ~ e n ~ L a ~ H a - ~}$ bana, que le llegaba a Ponte por boca de unos periodistas en una mesa redonda televisiva, donde lo compararon, desdeñosamente con Mr. Wormold, mientras discutían los textos de la revista Encuentro de la Cultura Cubana, le sirve a Ponte para complejizar la oposición entre el registro de la vigilancia y la literatura, para volver a pensar en la verdad y en sus formas.

¿Qué novelas escriben los espías? ¿De qué lado se encuentra la ficción? ¿Cuáles fueron sus consecuencias? Y, especialmente, ¿cuál es su consistencia? ${ }_{\mathrm{C}}$ Existe un sustento que permita diferenciar archivo y vida cotidiana? Estas indistinciones, sostenidas por las tareas del espionaje, conforman el punto más siniestro y al mismo tiempo el más productivo del libro. Cuando Ponte narre la escena de su "desactivación" de la Unión de Escritores, justamente recuperará la oposición entre la materialidad de la escritura y el aire, entre la ciudad letrada y el fantasma:

Días más tarde, en una terraza de la Unión de Escritores, dos funcionarios me notificaron la expulsión de la ciudad letrada: en adelante ningún trabajo mío podría aparecer en las revistas y editoriales del país, suspenderían cualquier presentación en público que intentara [...] las sanciones podrían levantarse en dependencia de mi conducta futura, yo podría apelar de inmediato.

13 En La fiesta vigilada abundan las relaciones entre la tarea del espía y la del novelista. Aquí apunto algunas: "Greene anda lejos de pretender una espesa ilusión de realidad, no procura esta vez que su lector olvide lo metido que está en un simulacro. Más bien lo opuesto: Our man in Havanna no es precisamente una historia de espías, sino la historia de cómo puede inventarse una historia de espías. De cómo un simulacro cobra animación [...] Wormold no hace ni más ni menos que el trabajo de un escritor de ficción" (54). "Graham Greene había llegado a calibrar cuánto tienen en común espía y novelista desde que ambos observan y escuchan con disimulo, buscan motivos, analizan sujetos y, empeñados en servir a la patria o a la literatura, carecen de escrúpulos. A diferencia suya, la atracción de Garton Ash por el espionaje formaba parte de un ramillete de intereses diversos que incluía el teatro, la arquitectura moderna, la literatura y la política" (216 y 217). 
Tal apelación debería constar por escrito en misiva dirigida al presidente de la Unión de Escritores. La institución, en cambio, no ofrecería por escrito noticia del castigo. [...]

Yo tendría que apelar por escrito a una sanción hecha en el aire [...]. Al parecer, la institución blanqueaba desde ya sus archivos. Cualquier investigador futuro, por suspicaz que fuera, podría revisar la documentación salvaguardada en aquel edificio.

“¿Prohibido ese escritor de que me habla?", llegarían a desentenderse los responsables. "¿Y en cuál papel consta?".

Mi etapa de fantasma comenzaba sin prueba alguna. (La fiesta 41-46)

La misma contraposición irá a repetirse cuando narre el caso de Timothy Garton Ash, el historiador británico que, de aspirante a espía a investigador espiado, se encontró con el registro de su vigilancia y las conclusiones que ello le deparó. "Los efectos de leer un expediente pueden ser terribles", declaraba, porque abrían coartadas para el victimismo y el resentimiento, chantajes sobre una vida "novelesca" o "interesante". Y sobre todo porque en el tránsito de dicha investigación, en las entrevistas a los delatores, Garton Ash corroboraba, a causa de la sistemática destrucción de archivos y de la obediencia acusada por los chivatos, que "el mal tenía tanta consistencia como una nube [...] el gran mal era la suma de muchas acciones fatalmente dispersas en minucias" (Ponte, La fiesta 230).

En suma, Mr. Wormold escribe fantasmas que se encarnan en la realidad e inventa documentación de una intriga que no existió; Garton Ash se encuentra con personas que se consideran "novelescas" por haber sido espiadas; G. descubre que acciones como entrar a casa, recibir un amante o bajar una ventana fueron registradas y leídas en clave, en función del relato que se busca inventar o sostener, y el propio autor, por escribir un texto crítico al régimen, se desintegra, encuentra borrado su nombre del campo intelectual. La contracara del archivo es el aire.

No obstante, la oposición en torno al significante "aire" no remite a una pura negatividad. Repone una serie de términos positivos, vinculados, nuevamente, con el archivo cubano. En un ensayo anterior del autor, "El abrigo del aire", la materialidad aérea funcionaba como el vector de una tradición en la literatura nacional, en particular la de José Martí. Indispensable como el aire, según Eliseo Diego, evasiva como el aire, según lo recordaba Baralt. Pensar la tradición significaba para Ponte someter a la crítica los ropajes que cubrían la figura etérea de Martí, evitar que ingresen al museo, que se fetichicen. Del mismo modo que hicieron con su abrigo Henríquez Ureña y Alfonso Reyes, la figura de 
Martí no debe cristalizarse en una vitrina, sino ponerse en uso. ${ }^{14}$ Así, lo que toma la forma de hueco, de horadación en la vasija y en la pared, que, según vimos al comienzo, armaba la correlación entre ruinas y espionaje, coloca a la sospecha y a la vigilancia como dispositivo de lectura, pero también como dinámica de escritura, en el revés de la monumentalización y el museo. ${ }^{15}$

En El libro perdido de los origenistas, Ponte argumentaba que lo esencial cubano siempre fue conceptualizándose a partir de la proliferación de metáforas del vacío. El libro perdido aparece como epicentro de los modos de narrar la historia y la identidad cubana por tres escritores del grupo Orígenes: José Lezama Lima, Eliseo Diego y Cintio Vitier. Aunque, justamente, la abundancia de esa escritura sobre el vacío lleve al autor a reflexionar sobre su condición paradójica: el reaseguro de su memoria, en la misma década, sostiene, los tres escribieron la escena del libro perdido y de su imposible recuperación:

En una misma década, por los mismos años, tres escritores origenistas enarcan de nuevo un tema que les ha sido obsesivo. Siguen hablando de lo histórico cubano como de un cuerpo hurtado [...] Mientras escriben del vacío van terminando páginas que nosotros, históricamente venidos después de José Martí, después del grupo Orígenes, examinamos. Ya resulta difícil no sentir el lleno de esas páginas origenistas. Libros escritos sobre el vacío, comienzan a ocupar el vacío del que hablan. $(33)^{16}$

14 "Cabe imaginar entonces que Henríquez Ureña, que Reyes, que las desconocidas parientas de Martí, entendieron muy bien, sin embargo, lo histórico en aquel abrigo y quisieron que, aún después de muerto su dueño, el abrigo fluyera, que no disminuyera en vida y continuara en su corriente vida propia. No quisieron congelar aquella prenda en el estar de un museo. Del mismo modo, lo escrito por Martí debería arriesgarse a la rotura, a la pérdida, a la pelea de perros de la crítica, para seguir fluyendo. Cien años después de muerto, José Martí debería estar en discusión. A la idea de un Martí que se construye cada día faltaría emparejar la de un Martí rompiéndose" (Ponte, "El abrigo", 83).

15 Mónica Bernabé observa que un procedimiento para la escritura cubana tiene que ver con el hacer de la escasez o la nada, una virtud. En "El cielo del paladar", Bernabé analiza la contraposición aire/alimento en Virgilio Piñera, Lezama Lima y Ponte, para marcar,justamente, los modos en que la carencia se transforma en forma de producción. La nada, el vacío, el aire serían metáforas para problematizar lo esencial cubano, una cuestión señalada por Ponte en $E l$ libro perdido de los origenistas.

16 En el artículo final del libro, "El libro perdido de los origenistas. Final", el autor traza la relación entre la carencia y sus diferentes valoraciones políticas y económicas por parte del grupo de Orígenes, para luego situar la caída en bloque del grupo de la república literaria, a partir de las escuchas que recayeron sobre Lezama Lima. En ese marco ubica, además, otra escena de desmaterialización: la quema en vivo de poemas realizada por Virgilio Piñera y narrada por Reinaldo Arenas. "Llegados a la consistencia de fantasmas, de muertos en vida (así llamó Piñera a su condición de escritor silenciado), la gente de Orígenes se encarga de hacer llegar el libro a 
No resulta casual, entonces, que el camino de configurar el archivo cubano hacia adentro de La fiesta vigilada se conforme como un proceso desmaterializador. La fiesta vigilada podría leerse en su totalidad como el transvase de una enorme cantidad de materiales a otro medio: el archivo que se construye en el libro. Como si volver a narrar el archivo cultural de La Habana, devorarlo o apropiarse de él, implicara su conversión a un formato aéreo, oral, liberado del peso de las carpetas, los volúmenes, las bibliotecas, los filmes. Como si, al igual que al abrigo de Martí, hubiera que convertirlo en aire, es decir, en fantasma: tan habitual que necesita ser mirado a través de la crítica y el recelo.

El libro de Ponte vendría a enfatizar y a reiterar que la singularidad del archivo cubano, a pesar de los intentos oficiales de museificación patrimonial, no deja de residir en la fabricación, una vez y otra, de formas de problematizar los soportes físicos de la memoria. Allí donde queramos detener la mirada siempre volvemos a encontrar sustracciones, hurtos, ausencias. ${ }^{17}$

En Bajo sospecha, Boris Groys parte de la idea de que el archivo de la cultura se encuentra siempre bajo amenaza de disolución. No existen certezas respecto de la duración de sus soportes mediáticos. El archivo, como aquello culturalmente valioso y separado del espacio profano, de la vida cotidiana, ostenta sobre sí la distancia entre sus signos y sus soportes, dejando entrever para el espectador un oscuro espacio submediático que no se confunde ni con el objeto del soporte ni con el texto del archivo cultural. En cuanto la sospecha configura el modo de relacionarse con el archivo, deja al descubierto, siempre parcialmente, el medio por el cual se viabiliza. Es la única manera, dice Groys, de confiar, aunque sea provisoriamente, en su duración. El archivo, entonces, se somete a una rearticulación constante de sus medios. Colocadas al comienzo y al final de La fiesta vigilada, las referencias al espionaje nos orientan en un archivo que se escribe hacia adentro, en los capítulos internos, cambiando su soporte de manera radical: ahora en una voz que vuelve a narrar los mismos textos y los filmes de la historia y la arquitectura habaneras. Que en suma, lo reproduce. Como aquel que permanece en vigilancia, repite y consigna lo que se ha escrito, lo que se ha escuchado y lo que se ha filmado; otorgando con ello la posibilidad de pensar en la intangibilidad y la reproductibilidad de un patrimonio, (¿a quién le pertenece,

lugar bien seguro. Parece acogerse a la exigencia de estos versos de Apollinaire: Perder / Pero perder de verdad / Para dar paso al hallazgo" (Ponte, El libro 172).

17 Una hipótesis en torno a la recursiva dificultad de la constitución del archivo cubano para los propios intelectuales de la isla desde finales de siglo XIX hasta la revolución de 1959 es ampliamente argumentada y desarrollada por Rafael Rojas en Tumbas sin sosiego. Revolución, disidencia y exilio del intelectual cubano. 
dónde se resguarda?) y en el modo de cuestionar el proceso de auratización que recaería en el archivo de la cultura cubana (¿cómo archivar la fiesta, la música o incluso, la Inteligencia?). ${ }^{18}$

En La fiesta vigilada, Ponte arma, desarma y critica dicha situación. A partir de la insistencia en las figuras de la ausencia o la horadación como materia constitutiva de la historia y la identidad, y mediante la vinculación con los documentos desclasificados y las novelas de espionaje de la Guerra Fría, singulariza las formas de una subjetividad que pervive bajo sospecha; a la intemperie, sin resguardo de la mirada o la escucha de los otros. El hueco en la pared, la vasija rota, no cesan de indicar la amenaza de un desmoronamiento, por el cual retornarán, de manera exterior y opresiva, las malas combinaciones y las conexiones forzadas sobre las vidas de las personas.

\section{Obras citadas}

Basile, Teresa, comp. La vigilia cubana: sobre Antonio fosé

Ponte. Rosario: Beatriz Viterbo, 2009. Impreso.

Bernabé, Mónica. "El cielo del paladar". El abrigo de aire: ensayos sobre literatura cubana. Eds. Mónica Bernabé, Antonio José Ponte y

Marcela Zanin. Rosario: Beatriz Viterbo, 2001. 23-36. Impreso.

Buck-Morss, Susan. Mundo soñado y catástrofe: la desaparición de la utopía de masas en el este y el oeste. Madrid: A. Machado, 2004. Impreso.

Bürger, Peter. Teoría de la vanguardia. Barcelona: Península, 1987. Impreso.

De la Nuez, Iván. "El hombre nuevo ante el otro futuro". Almanaque: Cuba y el día después. Ed. Iván De la Nuez. Barcelona: Mondadori, 2001. 9-20. Impreso.

De la Nuez, Iván. Fantasía roja: los intelectuales de izquierdas y la revolución cubana. Madrid: Debate, 2006. Impreso.

Derrida, Jacques. Mal de archivo, una impresión freudiana. Madrid: Trotta, 1997. Impreso.

Díaz Infante, Duanel. La revolución congelada: dialécticas del castrismo. Madrid: Verbum, 2014. Impreso.

18 En "Museos, enciclopedias y mercados: notas sobre una hegemonía en disputa", publicado en El valor de la cultura: arte, literatura y mercado en América Latina, Álvaro Fernández Bravo desarrolla de Mario de Andrade el anteproyecto para la creación del Servicio de Patrimonio Histórico Artístico Nacional de 1936 y el Anteproyecto de la Enciclopedia Brasilera, de 1939, de incorporar al museo el registro y la reproducción de un "patrimonio intagible", proveniente de la cultura popular. Bravo pone el relieve en cómo dicho proyecto desmontaba el valor cultual de la obra de arte, al buscar los modos de su reproductibilidad y sus articulaciones con el mercado. 
Farge, Arlette. La atracción del archivo. Valencia: Institució

Valenciana D'estudis i Investigación, 1991. Impreso.

Fernández Bravo, Álvaro. "Museos, enciclopedias y mercados: notas sobre una hegemonía en disputa". El valor de la cultura: arte, literatura y mercado en América Latina. Comps. Luis E. Cárcamo-Huechante, Álvaro Fernández Bravo y Alejandra Laera. Rosario: Beatriz Viterbo, 2007. 161-178. Impreso.

Foster, Hal. "An Archival Impulse". October 110 (Autum 2004): 3-22. Impreso.

Foucault, Michel. "El enunciado y el archivo". Arqueología del saber. Buenos Aires: Siglo XXI, 2013. 103-173. Impreso.

Freud, Sigmund. "La pérdida de la realidad en la neurosis y la psicosis". Obras completas. Volumen 19 (1923-25): el yo y el ello y otras obras. Traducción directa del alemán de José L. Etcheverry. Buenos Aires: Amorrortu, 1979. 189-197. Impreso.

Greene, Graham. Nuestro hombre en La Habana. Barcelona: Bruguera, 1980. Impreso.

Groys, Boris. Bajo sospecha: una fenomenología de los medios. Valencia: Pre-Textos, 2008. Impreso.

Groys, Boris. Obra de arte total Stalin. Valencia: Pre-Textos, 2008. Impreso.

Garbatzky, Irina. "El archivo como productor: el lugar del uso en El deseo nace del derrumbe, de Roberto Jacoby". Anos 90 21.40 (2014): 311-331. Impreso.

Huyssen, Andreas. En busca del futuro perdido: cultura y memoria en tiempos de globalización. Buenos Aires: Fondo de Cultura Económica, 2001. Impreso.

López, Magdalena. "Espías y detectives calibánicos: marcando y difuminando los límites de la nación cubana revolucionaria". Revista Iberoamericana LXXVI.232-233 (2010): 671-693. Impreso.

Miranda, Jorge Cabezas (Ed.). Revista Diáspora(s). Edición facsímil. Barcelona: Lingkua, 2013. Impreso.

Morán, Francisco. "Un asiento y Ponte, entre las ruinas". La vigilia cubana: sobre Antonio fosé Ponte. Comp. Teresa Basile. Rosario: Beatriz Viterbo, 2009. 43-72. Impreso.

Ponte, Antonio José. "El abrigo del aire". El abrigo de aire: ensayos sobre literatura cubana. Eds. Mónica Bernabé, Antonio José Ponte y Marcela Zanin. Rosario: Beatriz Viterbo, 2001. 73-84. Impreso.

Ponte, Antonio José. El libro perdido de los origenistas. Madrid: Renacimiento, 2004. Impreso.

Ponte, Antonio José. La fiesta vigilada. Barcelona: Anagrama, 2007. Impreso.

Ponte, Antonio José. "Un arte de hacer ruinas". Cuentos de todas partes del Imperio. Angers: Deleatur, 2000. 23-40. Impreso. 
Quintero Herencia, Juan Carlos. Fulguración del espacio: letras e imaginario institucional de la Revolución Cubana (19601971). Rosario: Beatriz Viterbo, 2002. Impreso.

Quiroga,José. Cuban palimpsests. Minneapolis: University of Minesotta Press, 2005. Impreso.

Rodríguez, Juan Carlos. "Tiene que suceder algo, tiene que destriunfar la revolución: una conversación con Antonio José Ponte". La Habana Elegante. Segunda Época 46 (2009). Web. 7 de mayo de 2015. Impreso.

Rojas, Rafael. Tumbas sin sosiego: revolución, disidencia y exilio del intelectual cubano. Barcelona: Anagrama, 2006. Impreso.

Rojas, Rafael. El estante vacío: literatura y política en Cuba. Barcelona: Anagrama, 2009. Impreso.

Silva, María Guadalupe. "Antonio José Ponte: el espacio como texto". Iberoamericana 14.53 (2014): 69-83. Impreso.

Wacjman, Gérard. El objeto del siglo. Buenos Aires: Amorrortu, 2001. Impreso. Whitfield, Ester. "El presente en ruinas". La vigilia cubana: sobre Antonio fosé Ponte. Comp. Teresa Basile. Rosario: Beatriz Viterbo, 2009. 73-82. Impreso. 